\title{
PENGEMBANGAN MEDIA PEMBELAJARAN POP-UPSNAKES AND LADDERS PADA MATERI ARCHAEBACTERIA DAN EUBACTERIA KELAS X SMA/MA DI DAERAH PERBATASAN
}

\section{Development of Learning Media Pop-up Snakes and Ladders on Archaebacteria and Eubacteria Materials for Class X SMA/MA in Border Areas}

\author{
Nilam Novianti ${ }^{\mathrm{a}}$, Endik Deni Nugroho ${ }^{\mathrm{a}^{*}}$, Silfia Ilma ${ }^{\mathrm{a}}$ \\ a Program Studi Pendidikan Biologi, Universitas Borneo Tarakan, Tarakan, Kalimantan Utara \\ *Corresponding author: J1. Amal Lama, Tarakan Timur, Tarakan, Kalimantan Utara, 77123, Indonesia. E-mail: endwi.2011@gmail.com
}

\section{Abstrak}

Penelitian ini bertujuan untuk menganalisis kelayakan media pembelajaran Pop-up Snakes and Ladders pada materi Archaebacteria dan Eubacteria untuk kelas X SMA/MA di daerah perbatasan berdasarkan ahli materi, ahli media, ahli praktisi dan respon siswa. Penelitian yang digunakan adalah penelitian pengembangan atau Research and Development (R\&D) yang mengacu pada model 4-D (four D) yang dikembangkan oleh Thiagarajan, dkk. 1974. Model ini meliputi tahap pendefinisian (define), perancangan (design), pengembangan (develop) dan penyebaran (disseminate). Namun dalam penelitian ini, peneliti mengembangkan sampai tahap D yang ketiga, yaitu tahap develop dikarenakan keterbatasan waktu dan biaya.Hasil analisis validasi ahli materi diperoleh presentase sebesar 93,25\% dengan kategori sangat layak. Analisis ahli media diperoleh presentase sebesar $83 \%$ dengan kategori sangat layak. Sedangkan ahli praktisi diperoleh presentase sebesar $88 \%$ dengan kategori sangat layak. Dari hasil analisis data secara keseluruhan, maka dapat disimpulkan media yang dikembangkan telah memenuhi standar kelayakan media dengan tingkat kelayakan yaitu sangat layak sebagai media pembelajaran.

Kata kunci: Archaebacteria dan Eubacteria, Media Pembelajaran, Pop-up, Snakes and Ladders.

\begin{abstract}
The purpose of the research is to analyze the feasibility of learning media Pop-up Snakes and Ladders on Archaebacteria and Eubacteria materials for class X SMA / MA in border area based on material expert, media expert, practitioner and student response. The research used research development or Research and Development $(R \& D)$ which refers to 4-D model (four D) developed by Thiagarajan, et al. 1974. This model includes definitions, design, development and disseminate. But in this research, the researchers only develop media to the third of D stage, namely the development stage due to time and cost constraints. The result of the validation analysis of the material expert obtained percentage of $93.25 \%$ with very decent category. Expert analysis of media expert obtained percentage of $83 \%$ with very decent category. While expert practitioners obtained percentage of $88 \%$ with very decent category. From the results of data analysis as a whole, it can be concluded that the media developed has met the media feasibility standards with the level of feasibility is very feasible as a learning media.
\end{abstract}

Keywords: Archaebacteria and Eubacteria, Learning Media, Pop-ups, Snakes and Ladders. 


\section{Pendahuluan}

Pembelajaran merupakan suatu bagian yang tidak dapat dipisahkan dalam dunia pendidikan. Hal ini dikarenakan, pembelajaran juga ikut berperan aktif dalam mewujudkan kualitas pendidikan. Untuk meningkatkan hal tersebut, kemampuan seorang guru sangat dibutuhkan dalam melaksanakan atau mengemas suatu pembelajaran. Pada umumnya, seorang guru akan menggunakan sumber belajar dalam proses pembelajaran yang ia lakukan.

Asosiasi Teknologi Komunikasi Pendidikan (Association of Education and Communication Technology, AECT) menyatakan bahwa sumber belajar adalah semua sumber (baik berupa data, orang atau benda) yang dapat digunakan untuk memberi fasilitas (kemudahan) belajar bagi siswa. Dengan kata lain, sumber belajar sangat dibutuhkan oleh seorang guru dalam melakukan "transfer of knowledge" kepada siswanya di kelas. Salah satu komponen sumber belajar adalah media pembelajaran.

Anwar dan Harmi (2011) media pembelajaran adalah alat bantu yang digunakan guru dalam menyalurkan isi pelajaran. Sedangkan menurut Daryanto dan Dwicahyono (2009) media pembelajaran merupakan sarana atau alat terjadinya proses belajar mengajar. Jadi, media pembelajaran adalah suatu alat yang dapat mempermudah guru dalam melaksanakan proses pembelajaran. Penggunaan media pembelajaran sangat penting dalam proses belajar mengajar karena dapat meningkatkan proses pembelajaran yang ada agar pembelajaran dapat berlangsung secara maksimal, efektif dan efisien. Keberadaan media pembelajaran di sekolah sangat dibutuhkan, khususnya bagi sekolah-sekolah di daerah perbatasan.

SMA Negeri 1 Sembakung didirikan pada tanggal 17 Februari tahun 2006, terletak di Desa Atap, Kecamatan Sembakung, Kabupaten Nunukan, Provinsi Kalimantan Utara, tepatnya di Jalan Pendidikan RT 03. SMA Negeri 1 Sembakung merupakan satu-satunya SMA di desa tersebut dan termasuk sekolah yang berada di daerah perbatasan khususnya daerah 3T (Tertinggal, Terluar, dan Terdepan). Berdasarkan hasil observasi yang telah dilakukan di SMA Negeri 1 Sembakung selama PPL (November 2016 hingga Februari 2017) bahwa penggunaan media masih tergolong minim dan bersifat konvensional yaitu menggunakan papan tulis dan spidol.

Hasil penyebaran angket terhadap 25 siswa dari 84 siswa kelas X SMA Negeri 1 Sembakung pada tanggal 10 hingga 11 Maret 2017 diketahui bahwa pembelajaran Biologi di sekolah 32\% membosankan, 32\% menegangkan dan 20\% masih tergolong biasa saja. Sebanyak 52\% atau 13 siswa memilih sarana dan prasarana menjadi penyebab utama terkendalanya pembelajaran Biologi di sekolah. Sehingga hal ini yang mempengaruhi penggunaan media pembelajaran dalam proses belajar mengajar di kelas. Sebanyak $100 \%$ atau 25 siswa menyebutkan bahwa papan tulis dan spidol adalah media pembelajaran yang sering digunakan guru dalam melaksanakan pembelajaran Biologi di kelas. Jadi, dengan kata lain media ini menjadi media utama yang digunakan guru dalam mengatasi keterbatasan tersebut. Sehingga $48 \%$ atau 12 siswa mengaku media pembelajaran yang digunakan guru dalam pembelajaran Biologi di kelas belum menarik dan bahkan sebanyak 28\% atau 7 siswa mengatakan bahwa media pembelajaran yang digunakan masih tergolong biasa bagi mereka. Semua siswa yang diobservasi mengharapkan media pembelajaran Biologi yang inovatif, kreatif dan menyenangkan.

Berdasarkan hasil wawancara dengan salah satu guru mata pelajaran Biologi kelas $\mathrm{X}$ yang juga menjabat menjadi kepala sekolah SMA Negeri 1 Sembakung mengatakan bahwa proses pembelajaran di sekolah pada umumnya terkendala oleh fasilitas yang kurang memadai dan beberapa siswa masih ada yang kurang fokus dengan proses belajar mengajar yang berlangsung. Beliau mengakui metode pembelajaran masih tergolong kurang. Selain itu juga, 


\section{$[\pi$ \\ BJBE}

beliau mengatakan bahwa perlu dikembangkan media pembelajaran Biologi yang bersifat sederhana dalam penggunaannya.

Berawal dari permasalahan di atas, maka masalah yang ditemukan yaitu kurangnya penggunaan media pembelajaran yang bervariasi pada mata pelajaran Biologi akibat keterbatasan sarana dan prasarana sekolah. Hal ini menjadi penyebab banyak siswa yang mengalami kejenuhan dengan pembelajaran tersebut karena diakui atau tidak, realitas pembelajaran yang ada cenderung berjalan secara statis, rutinitas dan monoton sehingga membuat suasana di kelas menjadi tidak nyaman, menegangkan hingga menakutkan bagi siswa itu sendiri. Akibatnya, banyak siswa yang tidak menyukai pelajaran Biologi yang ada bahkan beberapa siswa mengakui tidak memiliki minat belajar pada mata pelajaran tersebut.

Hal tersebut yang membuat siswa sulit menerima materi pelajaran yang disampaikan hingga akhirnya mempengaruhi hasil belajar yang ada. Berdasarkan hasil belajar siswa berupa transkrip nilai murni pada semester ganjil diketahui bahwa nilai rata-rata mata pelajaran Biologi di sekolah tersebut jauh dibawah nilai KKM yaitu hanya sebesar 33.94 dengan rincian setiap kelas yakni kelas X-A sebesar 38.34, kelas X-B sebesar 26.40 dan kelas X-C sebesar 37.07 .

Hal ini tentunya sangat memprihatinkan dan menjadi tugas yang sangat berat bagi guru yang bersangkutan. Untuk itu, demi membantu pembelajaran Biologi di sekolah tersebut agar lebih menyenangkan, diminati dan mudah dipahami solusi yang dapat dilakukan berdasarkan permasalahan di atas yaitu dengan mengembangkan media pembelajaran yang berkesan bagi siswa. Salah satu metode dalam pengembangannya yaitu dengan pendekatan sistem bermain sambil belajar. Jeanette Vos dan Gordon Dryden (Yudha, 2010) mengatakan bahwa "Learning is most effective when it's fun".

Bentuk produk media yang akan dikembangkan adalah permainan snakes and ladders yang dimodifikasi kedalam bentuk 3D dengan menggunakan paper engineering berbasis popup. Desain Grafis Indonesia (DGI) mengartikan pop-up sebagai bagian dari salah satu bidang kreatif pada paper engineering yang menampilkan bentuk 3 dimensi atau timbul dalam sebuah karya. Pemilihan teknik ini akan difokuskan pada materi yang tergolong sulit di kelas $\mathrm{X}$ dalam mata pelajaran Biologi. Karena elemen kejutan dalam bentuk pop-up, akan memberikan penekanan pada materi tersebut.

Penggunaan teknik ini didasarkan pada penelitian yang dilakukan Lismayanti, dkk (2016) yang menjelaskan bahwa рор-up mempunyai kemampuan untuk memperkuat kesan yang ingin disampaikan dalam suatu materi sehingga materi lebih mudah diingat dan dipelajari. Penggunaan рор-ир selalu menarik karena selalu memberikan kejutan-kejutan di dalamnya. Selain itu, Yulianto (2016) menjelaskan bahwa penggunaan snakes and ladders efektif dalam memberikan motivasi belajar.

Materi Archaebacteria dan Eubacteria adalah salah satu materi yang ada dalam mata pelajaran Biologi di kelas X SMA/MA pada semester ganjil. Materi ini mencakup deskripsi dari ciri-ciri Archaebacteria dan Eubacteria hingga peranannya dalam kehidupan. Menurut 56\% atau 14 siswa berpendapat bahwa materi ini tergolong cukup sulit dan $36 \%$ atau 9 siswa menganggap materi ini tergolong sulit bagi mereka. Pendapat ini didukung oleh guru mata pelajaran yang bersangkutan, beliau juga mengakui bahwa materi ini tergolong sulit. Alasannya karena keterbatasan fasilitas dalam melaksanakan proses pembelajaran yang ada.

Siswa kurang memahami konsep dasar pada materi ini dan siswa menjelaskan bahwa materi ini tergolong sulit dipahami karena penyebutan contoh spesies dalam nama-nama ilmiah yang membuat lidah mereka terbelit dalam pelafalannya. Selain itu, siswa juga menyebutkan masih sulit membedakan konsep antara Archaebacteria dan Eubacteria. 


\section{BJBE}

Berdasarkan uraian di atas, peneliti merasa perlu dikembangkan suatu media pembelajaran sesuai dengan permasalahan yang ada. Untuk itu, peneliti mencoba mengembangkan sebuah media pembelajaran melalui penelitian yang berjudul "Pengembangan Media Pembelajaran Pop-Up Snakes and Ladders pada Materi Archaebacteria dan Eubacteria untuk Kelas X SMA/MA di Daerah Perbatasan"

\section{Material dan Metode}

Jenis penelitian yang digunakan adalah penelitian pengembangan atau Research and Development (R\&D) yang mengacu pada model 4-D (four D) yang dikembangkan oleh Thiagarajan, dkk. 1974. Model ini meliputi tahap pendefinisian (define), perancangan (design), pengembangan (develop) dan penyebaran (disseminate). Namun dalam penelitian ini, hanya mengembangkan sampai tahap D yang ketiga, yaitu tahap develop dikarenakan keterbatasan waktu dan biaya.

Pada penelitian ini dilakukan penilaian produk dan pengujian produk. Subjek uji coba yang terlibat yaitu 25 siswa kelas XI IPA SMA Negeri 1 Sembakung yang telah mengampuh materi Archaebacteria dan Eubacteria. Materi ini merupakan materi kelas X pada semester ganjil. Sedangkan objek uji coba yang diteliti adalah kualitas media pembelajaran yang meliputi aspek kurikulum, penyajian materi, tata bahasa, keinovatifan media, kualitas tampilan, tingkat keawetan bahan, ukuran media, komposisi warna, dan keterpakaian.

Jenis data yang digunakan dalam penelitian ini yaitu data kualitatif dan data kuantitatif. Data kualitatif diperoleh dari validitas ahli materi, ahli media, ahli praktisi dan respon siswa berupa saran dan komentar tentang produk yang dikembangkan melalui angket yang diberikan. Data kuantitatif diperoleh dari skor penilaian dari validitas ahli materi, ahli media, ahli praktisi dan respon siswa terhadap produk yang dikembangkan melalui angket yang diberikan.

Teknik analisis yang digunakan dalam penelitian dan pengembangan ini yaitu dengan cara mengumpulkan data melalui instrumen yang digunakan. Instrumen yang digunakan yaitu angket atau kuesioner dengan menggunakan skala Likert 5 interval. Skala Likert adalah skala yang digunakan untuk mengukur sikap, pendapat, dan presepsi seseorang atau sekelompok orang tentang fenomena sosial (Sugiyono, 2016).

Tabel 1. Aturan Pemberian Skor Validasi

\begin{tabular}{lc}
\hline \multicolumn{1}{c}{ Kriteria } & Skor \\
\hline Sangat baik & 5 \\
\hline Baik & 4 \\
\hline Cukup baik & 3 \\
\hline Kurang baik & 2 \\
\hline Sangat kurang baik & 1 \\
\hline
\end{tabular}

Sumber: Sugiyono (2016)

Untuk memperoleh presentase kelayakan media yang dikembangkan digunakan rumus sebagai berikut:

$$
P=\frac{\sum X}{\sum X_{i}} x 100 \%(\text { Arikunto, 2006) }
$$

Keterangan:

$P \quad=$ Presentase yang dicari 


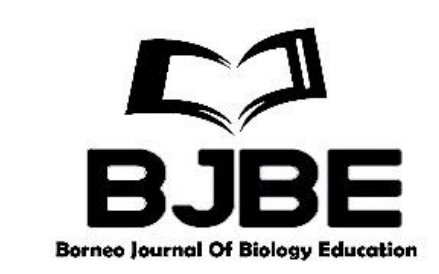

$\sum X=$ Jumlah nilai jawaban responden

$\sum X_{i}=$ Jumlah nilai ideal

Untuk mengetahui standar kelayakan media yang dikembangkan, data hasil presentase kemudian di interpretasikan.

Tabel 2. Kriteria Kelayakan Media

\begin{tabular}{ccc}
\hline No. & Kriteria Kelayakan & Tingkat Kelayakan \\
\hline 1. & $81,00-100,00$ & Sangat layak \\
\hline 2. & $61,00-80,00$ & Layak \\
\hline 3. & $41,00-60,00$ & Kurang Layak \\
\hline 4. & $21,00-40,00$ & Tidak Layak \\
\hline 5. & $00,00-20,00$ & Sangat Tidak Layak \\
\hline
\end{tabular}

Sumber: Akbar (2013) dengan modifikasi.

Media yang dikembangkan dikatakan layak digunakan apabila hasil data yang diperoleh setelah dianalisis sebesar $\geq 61 \%$ dengan tingkat kelayakan layak atau sangat layak. Untuk mengetahui hasil respon siswa terhadap media yang dikembangkan, angket yang diberikan dianalisis sesuai pada Tabel 3.

Tabel 3. Aturan Pemberian Skor Respon Siswa

\begin{tabular}{lc}
\hline \multicolumn{1}{c}{ Kriteria } & Skor \\
\hline Sangat Baik & 5 \\
\hline Baik & 4 \\
\hline Cukup Baik & 3 \\
\hline Kurang Baik & 2 \\
\hline Sangat Kurang Baik & 1 \\
\hline
\end{tabular}

Sumber: Sugiyono (2016)

Untuk memperoleh presentase respon siswa terhadap media yang dikembangkan digunakan rumus sebagai berikut:

$$
P=\frac{\sum X}{\sum X_{i}} x 100 \% \text { (Arikunto, 2006) }
$$

Keterangan:

$P \quad=$ Presentase yang dicari

$\sum X=$ Jumlah nilai jawaban responden

$\sum X_{i}=$ Jumlah nilai ideal

Untuk mengetahui respon siswa terhadap media yang dikembangkan, data hasil presentase kemudian di interpretasikan pada Tabel 4.

Tabel 4. Kriteria Respon Siswa

\begin{tabular}{ccc}
\hline No. & Kriteria Kelayakan & Tingkat Kelayakan \\
\hline 1. & $81,00-100,00$ & Sangat Baik \\
\hline 2. & $61,00-80,00$ & Baik \\
\hline 3. & $41,00-60,00$ & Kurang Baik \\
\hline
\end{tabular}




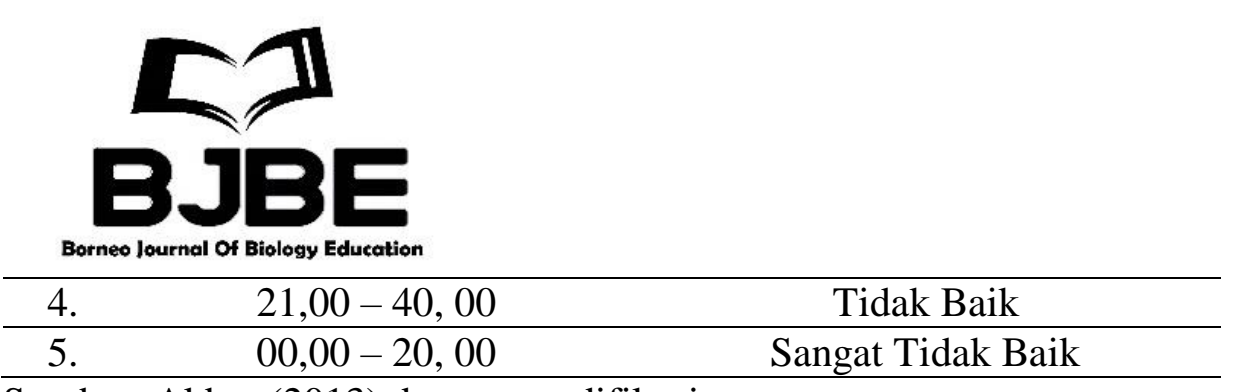

Sumber: Akbar (2013) dengan modifikasi.

Respon siswa terhadap media yang dikembangkan dikatakan baik apabila hasil data yang diperoleh setelah dianalisis sebesar $\geq 61 \%$ dengan tingkat respon siswa baik atau sangat baik.

\section{Hasil dan Pembahasan}

Media pembelajaran Pop-up Snakes and Ladders pada materi Archaebacteria dan Eubacteria merupakan media pembelajaran biologi yang difokuskan untuk siswa kelas $\mathrm{X}$ SMA di daerah perbatasan sebagai sasaran utama penggunaan produk. Media ini terbagi menjadi beberapa komponen, yaitu: Mainboard, Snakes and Ladders Guidebook, Bio Vocab, Bio Question, Bio Lesson, Reward Pocket, 1 dadu dan 4 bidak yang dikemas menjadi satu paket media pembelajaran biologi (Biology Game) didalam Box dan Paperbag yang dilengkapi dengan Label Name. Media ini divalidasi oleh tim ahli/pakar.

\section{Analisis Hasil Validasi Ahli Materi}

Hasil analisis validasi ahli materi terhadap media pembelajaran Pop-up Snakes and Ladders pada materi Archaebacteria dan Eubacteria untuk kelas X SMA/MA di daerah perbatasan disajikan dalam Tabel 5.

Tabel 5. Analisis Hasil Akhir Validasi Materi

\begin{tabular}{lcc}
\hline \multicolumn{1}{c}{ Aspek } & Presentase (\%) & Tingkat Kelayakan \\
\hline Kurikulum & $95 \%$ & Sangat Layak \\
\hline Penyajian Materi & $88 \%$ & Sangat Layak \\
\hline Tata Bahasa & $97 \%$ & Sangat Layak \\
\hline Keterpakaian & $93 \%$ & Sangat Layak \\
\hline Rata-rata & $\mathbf{9 3 , 2 5 \%}$ & Sangat Layak \\
\hline
\end{tabular}

Berdasarkan tabel diatas, diketahui bahwa rata-rata hasil analisis validasi ahli materi terhadap media pembelajaran Pop-up Snakes and Ladders pada materi Archaebacteria dan Eubacteria untuk kelas X SMA/MA di daerah perbatasan menunjukkan nilai presentase sebesar $93,25 \%$ dengan rincian nilai presentase masing-masing aspek yaitu $95 \%$ untuk kurikulum, $88 \%$ untuk penyajian materi, $97 \%$ untuk tata bahasa dan $93 \%$ untuk keterpakaian. Sehingga dapat disimpulkan bahwa Pop-up Snakes and Ladders pada materi Archaebacteria dan Eubacteria sangat layak dijadikan media pembelajaran untuk kelas X SMA/MA di daerah perbatasan.

Aspek penyajian materi hanya memperoleh presentase $88 \%$ berdasarkan penilaian ahli materi karena dalam penyajian konsep materi, terdapat kesalahan materi pada Bio Lesson nomor 2. Kartu ini memuat materi tentang perbedaan sel prokariot vs sel eukariot dimana pada kartu tersebut dijelaskan bahwa perbedaan diantara keduanya terletak pada ada tidaknya nukleus seharusnya perbedaan keduanya berdasarkan ada tidaknya membran inti. Selain itu, media yang dikembangkan masih menggunakan sumber gambar dari internet yang belum dapat dipertanggungjawabkan. Serta belum ada tabel khusus yang mencantumkan indikator pencapaian pembelajaran sesuai dengan letak materi pada kartu. 


\section{$[1$ \\ BJBE}

\section{Analisis Hasil Validasi Ahli Media}

Hasil analisis validasi ahli media terhadap media pembelajaran Pop-up Snakes and Ladders pada materi Archaebacteria dan Eubacteria untuk kelas X SMA/MA di daerah perbatasan disajikan dalam Tabel 6.

Tabel 6. Analisis Hasil Akhir Validasi Media

\begin{tabular}{lcc}
\hline \multicolumn{1}{c}{ Aspek } & Presentase (\%) & Tingkat Kelayakan \\
\hline Keinovatifan Media & $93 \%$ & Sangat Layak \\
\hline Kualitas Tampilan & $87,5 \%$ & Sangat Layak \\
\hline Tingkat Keawetan Bahan & $67 \%$ & Layak \\
\hline Ukuran Media & $75 \%$ & Layak \\
\hline Komposisi Warna & $90 \%$ & Sangat Layak \\
\hline Keterpakaian & $86 \%$ & Sangat Layak \\
\hline Rata-rata & $\mathbf{8 3 \%}$ & Sangat Layak \\
\hline
\end{tabular}

Berdasarkan tabel diatas, diketahui bahwa rata-rata hasil analisis validasi ahli media terhadap media pembelajaran Pop-up Snakes and Ladders pada materi Archaebacteria dan Eubacteria untuk kelas X SMA/MA di daerah perbatasan menunjukkan nilai presentase sebesar $83 \%$ dengan rincian nilai presentase masing-masing aspek yaitu 93\% untuk keinovatifan media, $87,5 \%$ untuk kualitas tampilan, ukuran media, $90 \%$ untuk komposisi warna dan $86 \%$ untuk keterpakaian.

Semua aspek ini termasuk dalam kategori sangat layak. Sedangkan untuk tingkat keawetan bahan nilai presentase hanya sebesar $67 \%$ dan untuk ukuran media hanya sebesar 75\%. Tingkat kelayakan pada kedua aspek ini termasuk dalam kategori layak. Hal ini dikarenakan bahan yang digunakan masih menggunakan bahan kertas sehingga dalam penggunaannya akan mudah robek atau tidak tahan lama. Namun, secara keseluruhan Pop-up Snakes and Ladders pada materi Archaebacteria dan Eubacteria sangat layak dijadikan media pembelajaran untuk kelas X SMA/MA di daerah perbatasan. Menurut Abrori, dkk. 2016, menyatakan media yang baik yaitu memenuhi kualitas tampilan, ada unsur inovasi dan penggunaan atau keterpakaian dalam pembelajaran sehingga menghasilkan pembelajaran yang berkualitas dan berdampak pada hasil belajar yang efektif

\section{a. Analisis Hasil Validasi Praktisi}

Hasil analisis validasi praktisi terhadap media pembelajaran Pop-up Snakes and Ladders pada materi Archaebacteria dan Eubacteria untuk kelas X SMA/MA di daerah perbatasan disajikan dalam Tabel 7.

Tabel 7. Analisis Hasil Akhir Validasi Praktisi

\begin{tabular}{lcc}
\hline \multicolumn{1}{c}{ Aspek } & Presentase (\%) & Tingkat Kelayakan \\
\hline Kurikulum & $90 \%$ & Sangat Layak \\
\hline Penyajian Materi & $85 \%$ & Sangat Layak \\
\hline Tata Bahasa & $90 \%$ & Sangat Layak \\
\hline Keinovatifan Media & $90 \%$ & Sangat Layak \\
\hline Kualitas Tampilan & $90 \%$ & Sangat Layak \\
\hline Tingkat Keawetan Bahan & $77 \%$ & Layak \\
\hline Keterpakaian & $92,5 \%$ & Sangat Layak \\
\hline Rata-rata & $\mathbf{8 8 \%}$ & Sangat Layak \\
\hline
\end{tabular}




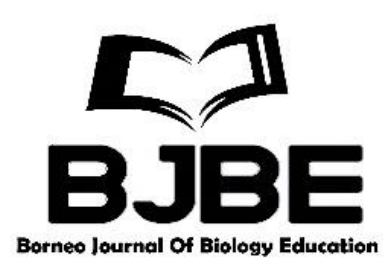

Berdasarkan tabel diatas, diketahui bahwa rata-rata hasil analisis validasi praktisi terhadap media pembelajaran Pop-up Snakes and Ladders pada materi Archaebacteria dan Eubacteria untuk kelas X SMA/MA di daerah perbatasan menunjukkan nilai presentase sebesar $88 \%$ dengan rincian nilai presentase masing-masing aspek yaitu $90 \%$ untuk kurikulum, $85 \%$ untuk penyajian materi, $90 \%$ untuk tata bahasa, $90 \%$ untuk keinovatifan media, $90 \%$ untuk kualitas tampilan dan $92,5 \%$ untuk keterpakaian.

Semua aspek ini termasuk dalam kategori sangat layak. Sedangkan untuk tingkat keawetan bahan nilai presentase hanya sebesar $77 \%$ dan menunjukkan tingkat kelayakan tergolong dalam kategori layak. Hal ini dikarenakan ukuran media yang kurang besar sehingga kurang mudah untuk dilihat. Namun, secara keseluruhan Pop-up Snakes and Ladders pada materi Archaebacteria dan Eubacteria sangat layak dijadikan media pembelajaran untuk kelas X SMA/MA di daerah perbatasan.

\section{Analisis Hasil Respon Siswa Terhadap Media}

Hasil analisis respon siswa terhadap media pembelajaran Pop-up Snakes and Ladders pada materi Archaebacteria dan Eubacteria untuk kelas X SMA/MA di daerah perbatasan disajikan dalam Tabel 8.

Tabel 8. Analisis Hasil Akhir Respon Siswa

\begin{tabular}{|c|c|c|c|}
\hline No. & Aspek & Presentase $(96)$ & $\begin{array}{l}\text { Tingkat Respon } \\
\text { Siswa }\end{array}$ \\
\hline 1. & $\begin{array}{l}\text { Menurut saya, pembelajaran Biologi kali ini } \\
\text { sangat menyenangkan. }\end{array}$ & $99 \%$ & Sanget Baik \\
\hline 2. & $\begin{array}{l}\text { Media "Pop- } D p \text { Snakes and Ladders" ini } \\
\text { gangat kreatif dan inovatif sebagai media } \\
\text { pembelajaran Biologi. }\end{array}$ & $97 \%$ & Sangat Baik \\
\hline 3. & $\begin{array}{l}\text { Saya tertarik dan termotivasi belajar biologi } \\
\text { menggunakan media "Pop- } U p \text { Snakes and } \\
\text { Ladiers" ini. }\end{array}$ & $98 \%$ & Sangzt Baik \\
\hline 4. & $\begin{array}{l}\text { Media "Pop- } U \text { p Snakes and Ladders" } \\
\text { membuat gaya minat belajar Biologi. }\end{array}$ & $94 \%$ & Sanget Baik \\
\hline 5. & $\begin{array}{l}\text { Saya senang belajar Biologi dengan media } \\
\text { "Pop- } U_{p} \text { Shakes and Ladders" daripada } \\
\text { mendengar penjelasan guru melalui papan } \\
\text { tulis dan spidol }\end{array}$ & $97 \%$ & Sanget Baik \\
\hline 6. & $\begin{array}{l}\text { Sayz lebih mudah memahami materi } \\
\text { Archab bacteria dan Eubacteria } \\
\text { menggunakan media "Pop-Up Snahes and } \\
\text { Ladiers" ini. }\end{array}$ & $95 \%$ & Sanget Baik \\
\hline 7. & $\begin{array}{l}\text { Sayz dapat memahami perbedazn konsep } \\
\text { antara materi Archacbacteria dan Eubacteria } \\
\text { menggunakan media "Pop-Up Snakes and } \\
\text { Ladders" ini. }\end{array}$ & $93 \%$ & Sangat Baik \\
\hline 8. & $\begin{array}{l}\text { Media "Pop- Dp Snakes and Ladabrs" ini } \\
\text { membantu saya dalam menyebutkan istilah } \\
\text { asing dalam materi Archabbacteria dan } \\
\text { Eubacteria. }\end{array}$ & $98 \%$ & Sanget Baik \\
\hline 9. & $\begin{array}{l}\text { Sayz dapat menggunalkan media "Pop- } D_{P} \\
\text { Srakes and Ladders" ini dengan mudah. }\end{array}$ & $95 \%$ & Sangat Baik \\
\hline 10 & $\begin{array}{l}\text { Saye dapat menggunakan media "Pop- } D P \\
\text { Srakes and Ladders" kapan saja dan dimana } \\
\text { gaja. }\end{array}$ & $93 \%$ & Sanget Baik \\
\hline 11. & $\begin{array}{l}\text { Sayz mendapat pengetahuan yang mendalam } \\
\text { tentang materi.Archas bacteria dan } \\
\text { Eubacteria dengan menggunakan media } \\
\text { "Pop-Up Snakes and Ladders" ini. }\end{array}$ & $98 \%$ & Sangat Baik \\
\hline 12 & $\begin{array}{l}\text { Sayz dapat mempelajari materi dengan } \\
\text { mudah karena konsep materi disajikan } \\
\text { dengan jelas melalui media "Pop-Up Snakes } \\
\text { and Ladbers". }\end{array}$ & $98 \%$ & Sangat Baik \\
\hline \multicolumn{2}{|c|}{ Kata-rata } & 9606 & Sangat Baile \\
\hline
\end{tabular}




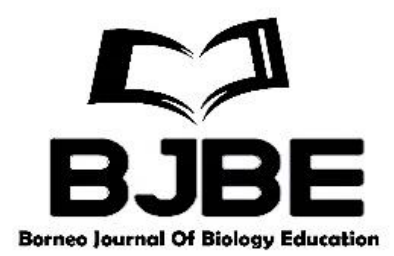

Berdasarkan tabel diatas diketahui bahwa rata-rata hasil analisis respon siswa terhadap media pembelajaran memperoleh presentase $96 \%$ sehingga menunjukkan tingkat kelayakan media dalam kategori sangat baik dari konsep penyajian materi hingga tampilan media pembelajaran yang ada.

Hal ini menunjukkan bahwa Pop-up Snakes and Ladders pada materi Archaebacteria dan Eubacteria sangat layak sebagai media pembelajaranuntuk kelas X SMA/MA di daerah perbatasan. Saran perbaikan dari siswa yaitu media Pop-up Snakes and Ladders ini dapat sering digunakan sebagai media pembelajaran dan perlu adanya tambahan fakta unik tentang Archaebacteria dan Eubacteria sehingga permainan lebih seru.

\section{Revisi Media Setelah Validasi oleh Ahli Materi}

Media yang telah divalidasi oleh ahli materi selanjutnya melalui tahap revisi. Tahap revisi terhadap media dilakukan berdasarkan masukan dari validator ahli materi yang diberikan pada tahap validasi terkait materi. Saran dari ahli materi dijadikan dasar untuk melakukan perbaikan pada materi. Pada penelitian ini, ahli materi menyarankan pengecekan kembali terhadap konsep karena terdapat kesalahan materi pada Bio Lesson nomor 2. Kartu ini memuat materi tentang perbedaan sel prokariot vs sel eukariot dimana pada kartu tersebut dijelaskan bahwa perbedaan diantara keduanya terletak pada ada tidaknya nukleus seharusnya perbedaan keduanya berdasarkan ada tidaknya membran inti.

Ahli materi juga menyarankan agar sebaiknya sumber gambar berasal dari sumber lain yang dapat dipertanggungjawabkan dan agar dibuatkan sebuah tabel khusus yang mencantumkan indikator pencapaian pembelajaran dengan letak materi yang sesuai. Misalnya, perbedaan sel prokariot dan eukariot pada bagian Bio Lesson dan seterusnya.

\section{Revisi Media Setelah Validasi oleh Ahli Media}

Media yang telah divalidasi oleh ahli media selanjutnya melalui tahap revisi. Tahap revisi terhadap media dilakukan berdasarkan masukan dari validator ahli media yang diberikan pada tahap validasi terkait media. Saran dari ahli media dijadikan dasar untuk melakukan perbaikan pada media. Pada penelitian ini, ahli media menyarankan perlu adanya mix penggunaan variasi pop-up yang lebih variatif sehingga pengguna tidak bosan memainkan permainan.

Dalam hal ini, validator mengharapkan adanya penggunaan teknik pop-up terbaru yang bersifat lebih modern. Berdasarkan saran tersebut, dilakukan perbaikan dengan mengganti beberapa kartu dengan menggunakan teknik pop-up yang terbaru yang bersifat lebih modern yaitu penggunaan teknik $180^{\circ}$ pada beberapa kartu (Bio Lesson dan Bio Vocab). Contoh perbaikan dari ahli media dapat dilihat pada Tabel 9. 


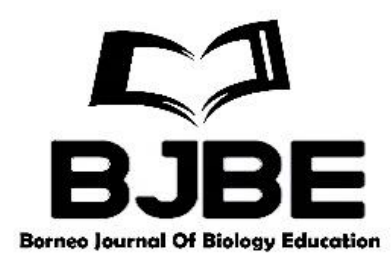

Tabel 9. Revisi Media oleh Ahli Media

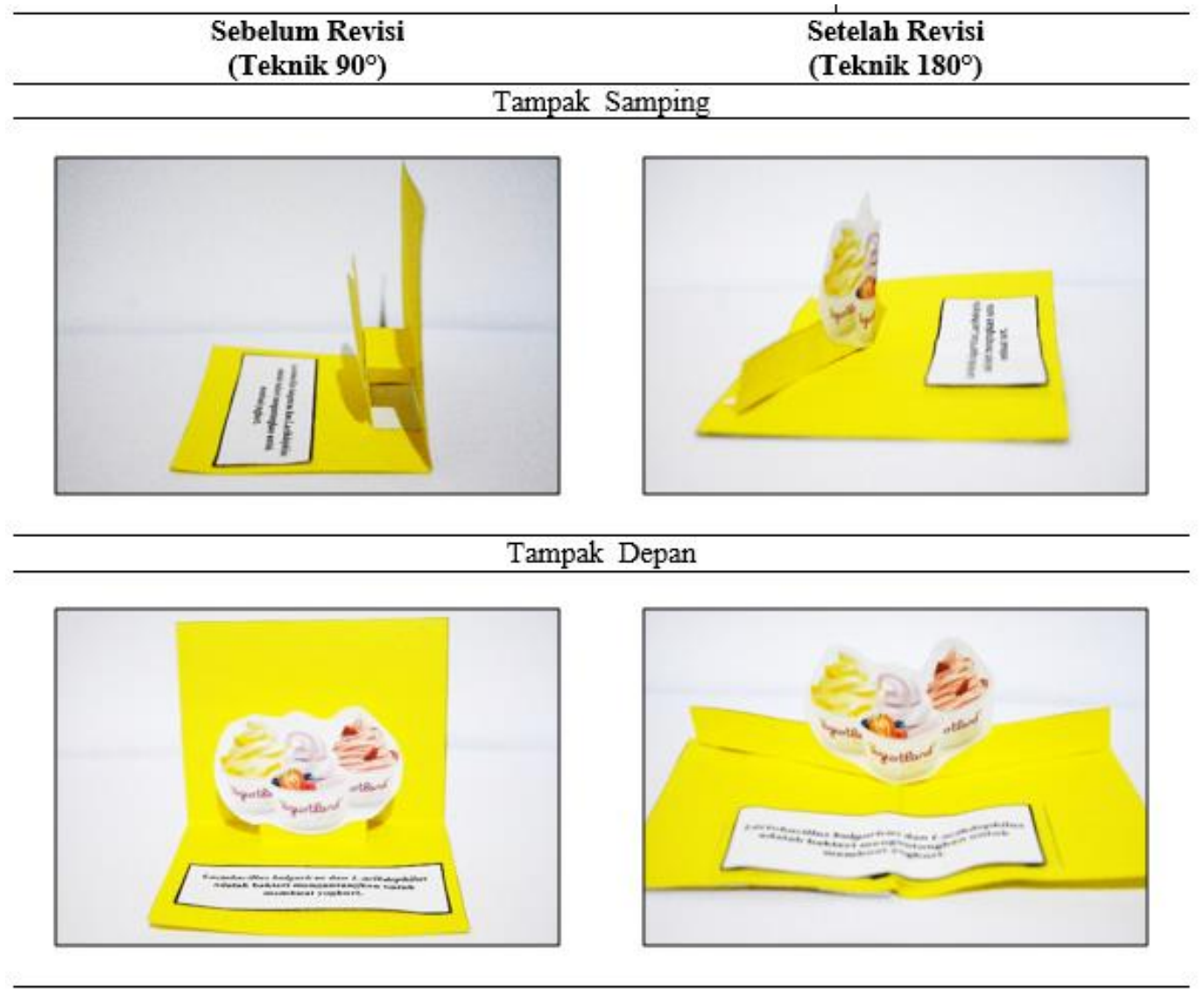

\section{Revisi Media Setelah Uji Coba Lapangan}

Media yang telah divalidasi oleh para ahli/pakar selanjutnya direvisi sesuai saran dan komentar yang terdapat pada lembar validasi. Setelah validator menyatakan media yang dikembangkan layak untuk diujicobakan maka selanjutnya dilakukan uji coba lapangan untuk mengetahui tingkat respon siswa terhadap media. Berdasarkan uji coba lapangan, siswa menyarankan perlu adanya tambahan fakta unik tentang Archaebacteria dan Eubacteria sehingga permainan lebih seru.

\section{Penutup}

Berdasarkan hasil penelitian dan pembahasan dapat disimpulkan bahwa Pop-up Snakes and Ladders pada materi Archaebacteria dan Eubacteria untuk kelas X SMA/MA di daerah perbatasan sangat layak sebagai media pembelajaran dengan perolehan pesentase dari ahli materi sebesar 93,25\% (sangat layak), ahli media sebesar 83\% (sangat layak), ahli praktisi sebesar $88 \%$ (sangat layak) dan respon siswa sebesar $96 \%$ (sangat baik).

\section{Ucapan Terimakasih}

Kami mengucapkan terimakasih kepada Ketua Jurusan Biologi FKIP Universitas Borneo Tarakan beserta civitas akademik membantu kelancaran penelitian dan tak lupa kepada Kepala Sekolah SMA Negeri 1 Sembakung yang telah mengizinkan dan membantu penelitian sampai selesai. 


\section{DaftarPustaka}

Abrori, F. M., Yulida, R., Adhani, A., Wijarini, F., \& Nugroho, E. D. (2016). Media Pembelajaran Biologi. Yogyakarta: Genom

Akbar, Sa'dun. (2013). Instrumen Perangkat Pembelajaran. Yogyakarta: Remaja Rosda Karya.

Anwar, Kasful dan Hendra Harmi. 2011. Perencanaan Sistem Belajar Kurikulum Tingkat Satuan Pendidikan (KTSP). Bandung: Alfabeta

Arikunto, Suharsimi. (2006). Prosedur Penelitian: Suatu Pendekatan Praktek. Jakarta: Rineka Cipta

Budiati, Herni. (2009). Biologi: untuk SMA dan MA Kelas X. Jakarta: Pusat Perbukuan, Departemen Pendidikan Nasional.

Daryanto. (2009. Panduan Proses Pembelajaran Kreatif dan Inovatif: Teori dan Praktik dalam Pengembangan Profesionalisme bagi Guru. Jakarta: AV.

Daryanto dan Aris Dwicahyono. (2014). Pengembangan Perangkat Pembelajaran (Silabus, $R P P, P H B$, Bahan Ajar). Yogyakarta: Gava Media

Dewantari, Alit Ayu. (2014). Sekilas tentang Pop-Up, Flip the Flap and Movable Book. Tersedia pada online at http://dgi.or.id/read/observation/sekilas-tentang-pop-up-lift-theflap-dan-movable-book.html. Didownload pada tanggal 03 April 2017.

Firzad, E.B.A. (2015). Pembuatan Ilustrasi Buku Pop-Up sebagai Media Pengenalan Huruf dan Nama-Nama Binatang pada Anak Usia Dini. Skripsi. Universitas Negeri Semarang, Semarang (dipublikasikan).

Ibdah, Fatimah. (2015). Perkembangan Kognitif: Teori Jean Piaget. Jurnal Intelektualita. $3(1): 27-38$

Ifadhah, H.T, Bahrudin, M., Dewanto, T.H. 2015. Penciptaan Buku Ilustrasi Berbasis Pop-Up tentang Cerita Rakyat Danau Kastoba Bawean Sebagai Upaya Memperkenalkan Produk Budaya Lokal bagi Anak-Anak. Jurnal Desain Komunikasi Visual. 4(2): 1-10

Ives, Rob. (2009). Paper Engineering \& Pop-ups For Dummies. Indiana: Wisley Publishing.

Karimah, R.F., Supurwoko, Wahyuningsih, D. (2014). Pengembangan Media Pembelajaran Ular Tangga Fisika untuk Siswa SMP/MTs Kelas VIII. Jurnal Pendidikan Fisika. 2(1): 6-10

Lismayanti, M. Hamidah, A. Anggereini, E. (2016). Pengembangan Buku Pop-Up sebagai Media Pembelajaran pada Materi Crustacea untuk SMA Kelas X. Jurnal Penelitian Universitas Jambi Seri Sains. 18: 44-48

Miftah. M. (2013). Fungsi dan Peran Media Pembelajaran sebagai Upaya Peningkatan Kemampuan Belajar Siswa. Jurnal KWANGSAN. 1(2): 95-105

Monica dan Luzar, L.C. (2011). Efek Warna dalam Dunia Desain dan Periklanan. Jurnal HUMANIORA. 2(2): 1084-1096

Nurhaidha, Martica Nuary. (2016). Pengembangan Media "Woody Puzzle" Berbasis Pembelajaran TGT (Teams Games Tournaments) untuk Siswa Kelas VIII SMP Negeri 9 Tarakan. Skripsi. Universitas Borneo Tarakan, Tarakan (tidak dipublikasikan).

Nuronniyah, Nadlifatun. (2015). Pengembangan Permainan Ular Tangga (Snakes and Ladders) Sebagai Media Pembelajaran Sejarah Kelas XI di SMA Negeri 1 Demak Pada Materi Perang Melawan Keserakahan Kongsi Dagang Tahun Ajaran 2014/2015. Skripsi. Universitas Negeri Semarang, Semarang (dipublikasikan).

Prastowo, Andi. (2013). Pengembangan Bahan Ajar Tematik: Panduan Lengkap Aplikatif. Yogyakarta: DIVA Press. 


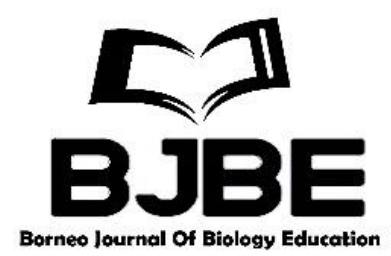

Puspitasari, Arum Talaria. (2015). Pengembangan Alat Peraga Miniatur pada Materi Ekosistem untuk Jenjang SMP/MTs Kelas VII di Kota Tarakan. Skripsi. Universitas Borneo Tarakan, Tarakan (tidak dipublikasikan).

Ratminingsih, N.M. (2016). Efektifitas Media Audio Pembelajaran Bahasa Inggris Berbasis Lagu Kreasi. Jurnal Pendidikan Indonesia. 5(1): 714-724

Sangadji, E.M. dan Sopiah. (2010). Metodologi Penelitian: Pendekatan Praktis dalam Penelitian. Yogyakarta: ANDI

Sugiyono. (2016). Metode Penelitian Kuantitatif, Kualitatif, dan R\&D. Bandung: Alfabeta

Sujarweni, V. Wiratna. (2014). Metodologi Penelitian. Yogyakarta: Pustaka Baru

Thiagarajan, S., Semmel, M.I., \& Semmel, D.S..(1974). Instructional Development for Training Teachers of Exceptional Childern: A Sourcebook. Indiana: The Center for Innovation in Teaching the Handicapped (CITH).

Trianto, (2007). Model Pembelajaran Terpadu Dalam Teori dan Praktek. Jakarta: Prestasi Pustaka

Wulandari. (2015). Pengembangan Modul Berbentuk Pop-Up dan Smash Book Materi Sistem Reproduksi Manusia di SMA Kesatrian 1 Semarang. Skripsi. Universitas Negeri Semarang, Semarang (dipublikasikan).

Yudha, Andi. (2010). Kenapa Guru Harus Kreatif?. Bandung: Mizan Pustaka

Yulianto, Nanang. (2016). Pengembangan Media Pembelajaran Ular Tangga untuk Meningkatkan Motivasi Belajar Siswa Kelas XI Akuntansi SMK Negeri 1 Klaten Tahun Ajaran 2015/2016. Skripsi. Universitas Negeri Yogyakarta, Yogyakarta (dipublikasikan). 